\title{
HOOFDTREKKEN DER WIJSGERIGE PROBLEMATIEK IN DE
}

HEDENDAAGSE MENS-BESCHOUWING*

De geschiedenis der wijsbegeerte valt slechts met vrucht te bestuderen, wanneer men bij haar tijdstroomingen en typen onderscheidt.

Tijdstroomingen treden achtereenvolgens op; de onderlinge verscheidenheid der typen daarentegen is die van denkers binnen dezelfde tijdstrooming. Ook de problematiek van die twee verschilt: de tijdstroomingen wijken onderling van elkander af in het antwoord op de vraag naar de plaats der wet, de typen echter door een grooter of kleiner verschil met betrekking tot de leer van de verticale structuur der dingen. Het minimum van historicale acribie vergt hier daarom de determineering van een conceptie naar tijdstroom en type.

De geschiedenis der wijsbegeerte in de Westeuropeesche cultuurkring ${ }^{1}$ ) is sinds de Renaissance daardoor gekenmerkt, dat, binnen het geheel dit tijdperk overheersende subjectivisme, $\left.{ }^{2}\right)$ de geleidelijke overgang van het vroege naar het late rationalisme, in de tweede helft der negentiende eeuw begon plaats te maken voor de tegenstelling van rationalisme en irrationalisme. In verband met deze tegenstelling onderscheide men na het voorspel van den nieuwen tijd (humanisme, renaissance en reformatie) twee hoofdperioden, de rationalistische en de irrationalistische.

De rationalistische hoofdperiode.

„Rationalisme" wil zeggen: „overschatting van de rede". Daarbij blijkt "rede" te betekenen niet - zoals in het Grieksche denken - „sprake”, „redevoering" of „betoogt”, maar „verstand toegerust met apriori's", inclusief dat van het bestaan der zintuigelijk waarneembare "qualiteiten".

De geschiedenis der rationalistische hoofdperiode valt uiteen in die van het vroege en van het late rationalisme.

I. Het vroege rationalisme (plm. 1600-plm. 1830).

Tijdens deze periode valt de nadruk op de inhoud der rede: de apriori's zijn niet aan de ervaring ontleende, maar aan deze

* Opgedragen aan mijn vriend en collega H. G. Stoker bij de intrede van zijn otium cum dignitate. 
voorafgaande begrippen en oordelen, uit welke wordt betoogd en geconcludeerd.

Daarbij valt bij het scientialisme de nadruk op de apriori's van wetenschappelijke aard; bij de Aufklärung daarentegen op de apriori's voor de praxis; het (oude) idealisme tenslotte tracht die twee te verbinden.

$\mathrm{Bij}$ alle verschil tusschen deze drie tijdstroomingen blijkt niet alleen het vroeg-rationalistische karakter, maar ook de reeds uit vroegere perioden stammende ontologisch gefundeerde verscheidenheid van hoofdgroepen, grondtypen en neventypen constant.

Als hoofdgroepen onderscheide men: mythologiserend, kosmogono-kosmologisch en louter kosmologisch denken; ${ }^{3}$ ) als grondtypen van iedere hoofdgroep dualisme en monisme; ${ }^{4}$ ) als neventypen bv. de dualisten zonder en met dichotomie bij het dualisme..$\left.^{5}\right)$

1. Het scientialisme (plm. 17e eeuw).

Afkerig van de scepsis der Renaissance menen de ontwerpers van "de grote systemen", dat de wetenschappelijke rede mede de praxis kan beheersen. Door deze eenzijdigheid bleef de invloed dezer strooming, hoe krachtig ook, uiteraard tot een vrij dunne bovenlaag beperkt.

Het scientialisme gaat intusschen niet op in een overschatting van de mathesis: laatstsbedoelde wetenschap raakt nl. uitsluitend het object, terwijl de scientialisten blijkens hun kentheorie mede oog hebben voor wetenschappen inzake het menselijk subject, dat de apriori's voor beide soorten van wetenschap in zich heeft: ook het scientialisme heeft zijn ethiek, esthetica enz.!

a. Mythologiseerend denken.

Hier verdienen vooral $\mathrm{H}$. More (dualist) en J. Law (monist) de aandacht in verband met hun verschil inzake het ruimtebegrip.

b. Kosmogono-kosmologisch denken.

Hier is speciaal het monisme van belang. Men onderscheide daarin wisselwerkingstheorie (Descartes, Mersenne en Hobbes), parallelisme (Spinoza en Leibniz) en prioriteitsleer (o.m. Geulincx, Malebranche en Newton). ${ }^{6}$ )

c. Louter kosmologisch denken.

Tegenover de enige monistische conceptie (het materialisme van Gassendi) staan hier verscheidene dualistische. 
Een dualisme met het thema van macro- en microkosmos treft men slechts aan bij het niet-spiritualistische semi-materialisme van Bayle. De overige dualisten in de louter kosmologische kring zijn allen min of meer aan de latere werken van Aristoteles georiënteerd. In deze kring onderscheide men empiristen (Locke en Granville) en intellectualisten. ${ }^{7}$ )

Van laatstbedoelde groep huldigde Vico in zijn eerste fase de semi-mystiek; belangrijker is het monarchianisme, dat met Berkeley en Collier twee nieuwe typen brengt.

2. De Aufklärung (plm. 18e eeuw).

Deze strooming brak met de eenzijdigheid der scientialisten: gevoel, taal en praxis in oeconomisch en etisch leven kunnen, evenmin als opvoeding en kunst niet door de wetenschap geregeld worden. Deze kritiek getuigt van werkelijkheidszin. Men verwarre deze trek vooral niet met empirisme. Want oppositie in deze zin was over de gehele linie nodig: Locke moest evenzeer door Hume worden gecorrigeerd als Descartes door Dubos, Mersenne door Condillac, Hobbes door Cabanis, Spinoza door Pistorius en Leibniz door Herder.

Nog minder zie men hier een breuk met het rationalisme: de theoretische "rede" werd slechts door de practische vervangen, zodat het rationalistisch mensbeeld destijds ook in tal van niet-wetenschappelijke kringen aan invloed won.

Door deze gang van zaken drong echter ook in deze nieuwaangeboorde lagen de tegenstelling door tusschen de gerustheid der monisten en de onrust der dualisten, die in het louter kosmologisch denken o.a. Condorcet en Vico (tweede periode) tot voorzichtigheid stemde, maar de voorstanders der cultuurkritiek met Rousseau's typisch dualistische probleem der ongelijkheid bij de Franse revolutie deed belanden.

3. Het (oude) idealisme (plm. 1775-1830).

De vervanging van de theoretische rede door de practische was echter even eenzijdig als het scientialisme: daardoor vergden beide groepen van concepties binnen het oude rationalisme een verbinding. De taak, deze combinatie tot stand te brengen, viel het oude idealisme ten deel.8)

De baanbreker dezer strooming was Immanuel Kant, die, na zowel door het scientialisme als door de Aufklärung te zijn heengegaan, tijdens zijn derde periode in zijn drie Kritiken het idealistische standpunt vertolkte. 
Ook tans handhaafde zich echter de verscheidenheid van groepen, hoofdgroepen en typen. Zo valt in het kosmogonokosmologisch idealisme bij het monisme van Kant en Lotze de prioriteitsleer, bij Rosmini-Serbati, Destutt de Tracy en Forberg de wisselwerkingstheorie, bij Herbart en Fechner het parallelisme en bij Hegel het contradictoire denken te herkennen, daarentegen bij Schopenhauer het dualisme, dat men bij J. G. Fichte in louter kosmologische zin aantreft.

II. Het late rationalisme (plm. 1805-plm. 1900).

Ook in deze periode overheerst nog het ideaal van „de redelijke mens".

Intusschen onderging dit mensbeeld een belangrijke wijziging: het neorationalisme benadert de rede niet meer qua inhoud, maar qua activiteit: de redelijke apriori's zijn thans niet begrippen en oordelen, maar methodes van onderzoek en aanpak.

Deze actieve rede wordt weer achtereenvolgens gezien als wetenschappelijk, practisch en als de verbinding van die twee. Derhalve onderscheide men ook hier een scientialistische, een praktische en een beide combineerende idealistische tijdstrooming. In verband met het gewijzigd karakter van het rationalisme duide men deze drie aan met de termen: positivisme, neopositivisme en neoidealisme.

\section{Het positivisme.}

Het baanbrekend werk dezer strooming was de Cours de Philosophie Positive van Aug. Comte (1830-'42), een louter kosmologisch denker.

Intusschen was het positivisme zelf ouder, getuige Comte's afhanklikheid van Saint-Simon en Lamennais alsmede het opkomen van het evolutionisme tusschen 1800 en 1810 . De eerste decennia van het positivisme vallen dus samen met de laaste van het oude idealisme.

Intusschen mene men niet, dat het evolutionisme geheel het positivisme beheerste: het treedt uitsluitend in het kosmogono-kosmologisch monisme op en dan nog slechts bij bepaalde typen.

A. Kosmogono-kosmologisch denken.

Monisme.

a. De evolutionistische typen. 
Het evolutionisme betreft niet één wetskring, maar de onderlinge verhouding van twee of meer rijken; het is dus niet vakwetenschappelijk, maar wijsgerig van aard.

Daarom behoort de bespreking van zijn karakter en innerlijke problematiek in de wijsbegeerte, terwijl zijn geschiedenis ook die van het mensbeeld sinds het begin van de $19 \mathrm{e}$ eeuw raakt.

Daarbij verdient al dadelijk de aandacht, dat deze visie slechts in bepaalde typen van genetische gedachtenconcepties voorkomt. Deze typen zijn alle monistisch. Aansluitend bij het optimistisch geloof aan vooruitgang in begrip en oordeel bij de geruste monisten der Aufklärung, poneert men thans voorts, positivistisch, dat de progressie in de eerste plaats de activiteit der rede betreft. Nu ziet de biologie terecht, dat een en ander niet tot het denken beperkt is: ook de metrische biotische vormen zijn niet stationair, maar resultaat van biotisch gekwalificeerde activiteit en deze is onder bepaalde omstandigheden voor wijziging vatbaar. Daarbij onderscheide men duidelijk de rijken (dat der fysisch gekwalificeerde dingen, de flora, de fauna - waarschijnlijk meer dan één rijk omvattend - en de mensheid) en de bij flora en fauna optredende (primair niet morfologisch, maar genetisch te definiëren) soorten.

Slechts op deze wijze immers is het mogelijk: 1e het gedragspatroon, dat mede de relatie van een subject uit een hoger rijk tot zijn ontische objecten (subjecten uit een lager rijk) betreft, en de kruisingsmogelijkheid, die uitsluitend de verhouding van subject tot medesubject binnen de mensheid resp. binnen de genetisch te definiëren soorten raakt, uiteen te houden; $2 \mathrm{e}$ bij de soorten het optreden van variëteiten en dat van echt nieuwe soorten te onderscheiden. In laatstbedoeld geval is dan uiteraard nog weer een criterium nodig om te beslissen, of men bij vollediger aangepastheid met devolutie dan wel met evolutie te maken heeft. Daar nu het evolutionisme deze voorwaarden echter niet in acht neemt, draagt zijn wijsbegeerte niet een wetenschappelijk, maar een speculatief karakter.

Wijl het evolutionisme voorts minstens eén rijk genetisch uit een lager afleidbaar acht, komt het slechts bij die typen van genetisch monisme voor, die in de hogere species der primaire divergentie minstens twee rijken aanwezig achten.

aa. In de wisselwerkingstheorie treft men evolutionisme 
niet slechts bij het zoölogisch-teleologische type aan (niet geheel doorgevoerd bij de Lamarck - 1809 -, daarentegen consequent doorgedacht bij Geoffry St. Hillaire - 1818 -, maar eveneens bij het fytologische $-\mathrm{Ch}$. Darwin -1859 ).

bb. In het beperkte parallelisme wordt het voorgestaan door Galton's "biométrie" - 1869 - en in het onbeperkte door Fechner's "Psychophysik" - 1860.

cc. $\mathrm{Bij}$ de prioriteitsleer met primaire impetustheorie is het zowel in instrumentistische als in vitalistische zin vertegenwoordigd door Maine de Biran (laatste twee fasen).

b. Daarentegen bieden het anthropologische type der wisselwerkingstheorie (St. Beuve) en de prioriteitsleer zonder impetustheorie (Cauchy en d'Alembert) geen mogelijkheid voor verbinding met evolutionisme.

ii. Dualisme.

Evenmin vindt men een dergelijke combinatie bij dualisten, bv. bij Burckhardt.

\section{B. Louter kosmologisch denken.}

Hier treden de dualisten op de voorgrond.

i. De aristoteliserende vleugel wordt beheerst door Auguste Comte, die in het triadische schema van zijn geschiedbeschouwing aan Condorcet was geöriënteerd en zijn ordeningsthema aan een tweetal voorgangers in het positivisme (Saint-Simon en Lamennais - eerste periode) ontleende.

ii. Op die vleugel der cultuurkritiek in niet spiritualistische zin staat Ludw. Feuerbach (laatste periode), bij wie korte tijd K. Marx aansloot: men denke aan diens aanvankelijk ideaal "het socialisme van ulopie tot wetenschap" te verheffen.

\section{Het Neo-positivisme.}

Deze strooming verhoudt zich tot de onmiddellijk voorafgaande zoals de Aufklärung tot het scientialisme der $17 \mathrm{e}$ eeuw.

De grote klacht, destijds tegen het (oude) positivisme ingebracht, was dan ook, dat dit de praxis geen recht liet wedervaren. Vandaar dat hier herhaaldelijk het practische denken met zijn tot waarden versubjectiveerde normen aan de orde komt.

A. Kosmogono-kosmologisch denken.

i. Prioriteitsleer. 
a. Met impetustheorie (evolutionistisch).

Félix Ravaisson Mollien (1813-1910), voornamelijk aan Maine de Biran (voorlaatste fase) geöriënteerd, herleidt de beweging van al het lagere (anorganisch en organisch) tot een stoot (impetus) vanuit het hoogere, dat alleen bij dier en mensch voorkomt. Het rechtstreeksche resultaat van deze stoot is bij beide de inspanning (l'effort) met haar passief gewaarworden en actief waarnemen. Daarbij verklare men niet de gewoonte uit de associatie van voorstellingsinhouden, maar, integendeel, laatstbedoelde uit de gewoonte. Hooger echter reiken wetenschap en kunst, die slechts bij den mensch optreden. Beide wortelen in de levende reflexie met haar gevoelige en intellectueele spontaneïteit. Van het instrumentisme onderscheidt deze conceptie zich door haar waardeering voor het soomatische en het schoone van zijn metrische vormen, nls verstarde bewegingen gezien. Een en ander is hier echter, anders dan bij Dilthey (eerste fase) ${ }^{9}$ ) in universalistischen zin uitgewerkt; vandaar dat het natuurschoon op den voorgrond staat en bij het artistieke schoon de technè terzijde blijft.

b. Daarentegen wordt de evolutionistische trek bestreden door $\mathrm{Ch}$. Renouvier en Tarde die de prioriteitsleer in occasionalistische zin huldigen.

ii. Wisselwerkingstheorie.

Terwijl het evolutionisme bij het anthropologische type (o.a. Cournot) ook hier ontbrak, ontmoet men het weer bij de twee andere typen: zoölogisch dachten W. James (le periode) en Guyau, fytologisch Engels, von Helmholz, Avenarius en Mach (laatste fase).

iii. Parallelisme.

Het beperkte vindt men in voluntaristische zin uitgewerkt bij W. Wundt, de stichter van de Leipziger school; het onbeperkte in artistieke zin bij F. A. Lange, de voorloper der Marburgers. Beiden denken evolutionistisch.

B. Louter kosmologisch denken.

i. Dualisme.

a. Op de aristoteliserende vleugel verdient de aandacht: aa. de invloed van Comte's semi-mystiek in het Italiaanse neopositivisme bij De Sanctis (middenperiode) en in het Duitse bij W. Windelband en H. Rickert (in beider eerste periode); bb. de versterking van het monopsychisme (Schupps en 


\section{G. Heymans).}

b. Op de cultuurkritische vleugel kwam Marx van zijn vroegere positivisme naar de praxis van het neopositivisme over, thans in spiritualistische geest in Frankrijk gesecundeerd door Proudhon.

ii. Monisme.

Het (atomistisch) materialisme van Dühring daarentegen zag zich door Marx en Engels bestreden.

C. Overgang van louter kosmologisch naar kosmogonokosmologisch denken.

Deze wending beheerst de gang van zaken in de aanvankelijk nog geheel neo-positivistische fenomenologie.

Haar vader, F. Brentano, dacht tot 1890 geheel in de geest der scholastiek. Daarbij huldigde hij een platoniserende subsistentietheorie, eerst slechts verbonden met de ponering van het immanente logische object (invloed op von Meinong), later nog gecombineerd met het reeds uit de late middeleeuwen stammende thema der intentionele Akte (invloed op C. Stumpf en Edm. Husserl in hun eerste werken).

Mettertijd ging echter Stumpf, enige jaren later gevolgd door Brentano en Husserl, naar de zoölogische wisselwerkingstheorie over, terwijl Brentano dit nog later weer door het fytologische type verving. Uiteraard impliceerde deze frontverandering, waarbij een louter kosmologisch dualisme zonder evolutionisme voor een kosmogono-kosmologisch monisme met evolutionisme plaats maakte, ingrijpende veranderingen zowel in de ontologie als in de kentheorie.

3. Het neo-idealisme.

Ook in het late rationalisme groeide de spanning tussen de overschatting van de theoretische en praktische rede.

Daarom bevreemdt het niet, dat men binnen het rationalistische kamp weer op een verbinding van het twee uit was. Zo kwam hier plm. 1870 het neo-idealisme aan bod.

A. Kosmogono-kosmologisch denken.

i. In het dualisme herleefde het pessimisme van Schopenhauer bij Ed. v. Hartmann.

ii. Het monisme vertoont ook nu sterke divergentie.

a. Hegels contradictoire denken vond vooral weerklank in Engeland; men denke hier niet slechts aan het semi-univer- 
salisme van Jos. Royce, maar vooral aan het universalisme van E. Caird en J. Watson.

b. In de prioriteitsleer greep E. Spranger, na met het neopositivisme van Dilthey's eerste fase te hebben gebroken, in neo-rationalistische en evolutionistische geest op het oude idealisme van W. von Humboldt terug; daarentegen koersten Liebmann en Lachelier op het kompas van Lotze en Kant.

c. In de wisselwerkingstheorie vertegenwoordigde Tannery het anthropologische type.

Bij de twee andere typen, beide evolutionistisch, onderscheide men tegen- en voorstanders van de fenomenologie. Bij het zoölogisch type verschillen onderling op dit punt von Kries en Edm. Husserl, die in 1907 zijn neopositivisme voor neoidealisme inruilde, gelijk bij het fytologische type Vaihinger en W. Schapp.

d. In het parallelisme vertegenwoordigt Al. Riehl met zijn ,kritisch realisme" de beperkte, de Marburgse school met haar „,kriticistisch idealisme” de onbeperkte richting.

B. Louter kosmologisch denken.

i. Bij het aristoteliserend denken staan onder de neoidealisten Rehmke, O. Külpe en J. Volkelt op het empiristische standpunt; de intellectualistische visie vindt men na hun overgang tot het neo-idealisme bij $\mathrm{W}$. Windelband en $\mathrm{H}$. Rickert eerst in semi-mystieke, later in monarchiaanse zin. Voorts verbonden A. Meinong en Jos. Geyser het werk van de vroege Brentano met het neo-idealisme in de zin van de Gegenstandstheorie resp. in die van de leer der, intentionele Akten".

C. Mythologiserend denken.

Ook in deze periode bleef het op de achtergrond. Toch ontbrak het niet geheel; de lijn H. More/R. Wagner keert terug bij een vriend van Dilthey, H. v. Stein, de monistische van Law/Schelling bij Dostojewski en in een fase van Berdiaeff; van meer belang zijn de mythologiserende analoga van de zoölogische wisselwerkingstheorie en van het parallelisme in het Cretisch-Dionysische en het Chaldees-astrologische type bij Nietzsche (voorlaatste periode) resp. bij Lasaulx en Vollgraf.

\section{De overgang van rationalisme naar irrationalisme.}

1. Tegenwoordig staan deze twee vaak scherp tegenover 
elkander: de irrationalist schrijft dan het tekort der wijsbegeerte van vroegere eeuwen op rekening van het rationalisme, teruijl de voorstander van deze strooming op de zwakheid van het irrationalisme wijst. Een en ander vergt nadere bezinning.

A. Retrospectief.

Ook wanneer men de kritiek van irrationalistische zijde delen zou, dient te worden opgemerkt, dat zij de moeilijkheden niet diep genoeg peilt: achter de overschatting van de rede ligt de apriorisatie van wat de Grieken als wetten beschouwden. Een gefundeerde kritiek zal dan ook, wat de Westerse wijsbegeerte betreft, tot de Grieken en zelfs tot de Preplatonici moeten doorstoten. En dan niet in de mening bij hen de basis te vinden voor rationalisme (Popper) of voor irrationalisme (Heidegger), maar om na te gaan, of hier inderdaad een wijsgerig betrouwbare basis lag.

\section{B. Vergelijkend.}

Irrationalisme en neo-rationalisme zijn, bij alle onderling verschil, het echter met elkander eens inzake bepaalde fundamentele oplossingen en belangrijke problemen. Voor de oplossingen denke men aan het subjectivisme, de accentuering van de activiteit en aan de constantheid der hoofdgroepen, grond- en neventypen. En wat de problematiek betreft, aan de kwesties rondom de onderlinge verhouding van evolutionisme en geschiedenisopvatting.

2. Een en ander liet zich verduidelijken door een nadere bestudering van enkele karakteristieke denkens, zó te kiezen dat iedere hoofdgroep uit de overgangstijd is vertegenwoordigd.

Daartoe lenen zich bijzonder drie figuren, die allen uit hetzelfde volk stammend, eerst het rationalisme waren toegedaan, maar later tot dezelfde tijdstrooming in het irrationalisme overgingen, nl. Nietzsche voor de mythologiserende, Dilthev voor de kosmogono-kosmologische en Troeltsch voor de louter kosmologische hoofdgroep.

A. Mythlogiserend denken.

F. Nietzsche (1844-1900), hoewel iets jonger dan Dilthey, kwam eerder dan deze aan het probleem rationalisme/irrationalisme toe. Daarom gaat hij hier voorop. 
i. De rationalistiese jaren $(-1883)$.

a. Tot $\mathbf{1 8 7 6}$ huldigde Nietzsche het oude idealisme in de zin van een, uiteraard niet evolutionistisch dualisme. Reeds tijdens deze fase ruilde hij het kosmogono-kosmologische denken (Schopenhauer) voor een Apollinisch-mythologiserend ( $R$. Wagner) in: de vernieuwing van het leven vergt religie en de beheerste muziek der tragedie.

b. (1876-'83). Na de breuk met Wagner blijkt Nietzsche, onder de invloed van P. Rée gekomen, neo-rationalistisch te denken. En wel in de geest van een aan de mythe van de Cretische Dionysos geöriënteerd neopositivisme, dat, als analogon der kosmogono-kosmologische zoölogische wisselwerkingstheorie, een niet-technicistisch, maar artistiek teleologisch evolutionisme impliceert. In het licht dezer conceptie wordt medelijden hier een machtsdrift, door welke men anderen, die zwakker zijn, aan zich binden wil; voor evolutie is echter moed nodig, die de gevaren van het kwade trotseert, daarbij niet meer mede door religie, maar slechts door de muziek thans die van bacchanten - aangevuurd.

ii. De irrationalistische jaren (1883-1900).

a. Tot 1891 bleef Nietzsche de Cretisch Dionysische mythe trouw. De geest is echter sterk gewijzigd. De apriori's van het verstand werden verworpen. En daarmee was de rede onttroond. Het ideaal is nu, boven de tegenstelling van goed en kwaad uit te komen: zij dient te worden vervangen door die van voornaam en laag. Dit vergt echter verheffing van het menstype. De evolutie blijft daarbij aanvaard. Maar ze heet thans toch ontoereikend: zij verklaart wel het verleden, maar inspireert niet tot daden, die nodig zijn om de toekomst te ontsluiten..Dit laatste is slechts mogelijk door het ideaal, de hoogst mogelijke ontplooiing van kracht en pracht, te bereiken. De „Lebensbejahung” is hier niet meer artistiek, maar werd een machtslust, die het pathos der distantie predikt: de gewone mens is slechts een koord tussen dier en „Ubermensch”, wellicht door opzettelijke teling voort te brengen.

b. (1891-...). Ook Nietzsche's laatste werk, Der Wille zur Macht, draagt een duidelijk mythologiserend karakter. Maar de mythe van de Cretische Dionysos, inclusief de combinatie van het thema der evolutie met de verwachting van de Ubermensch, is vervangen door de Chaldeesche, die eeuwige terugkeer van alle gebeuren verkondigt. Van de kern der geschiedenis bleef hier slechts de continuïteit bewaard. Maar in 
de geest van een visie, die krachtens haar parallelisme iedere partiële verantwoordelijkheid voor de gang der historie ontkent en door haar thema van de eeuwige wederkeer elke verwachting van een ware vernieuwing doodt.

B. Kosmogono-kosmologisch denken.

W. Dilthey (1833-1911).

Dilthey deelde steeds met Nietzsche (sinds diens overgang naar het neo-rationalisme) het monisme, maar verwierp krachtens zijn uitgangspunt, elke teologie.

i. De rationalistische jaren (plm. 1900).

Ten dele door Hegel beïnvloed, verwierp Dilthey niet slechts diens historicalistische vermenging van geschiedenis en begrip, maar evenzo het thema der universele coïncidentie der tegengestelden. Positief stond hij dichter bij Kant: ook Dilthey huldigde de prioriteitsleer. Maar, anders dan Kant, een prioriteitsleer met impetustheorie: het hogere brengt het lagere, dat op zichzelf star is, in beweging. Daardoor draagt het eerstbedoelde niet een logisch, maar een denkend, voelend en willend karakter en is het lagere niet psychisch-soomatisch, maar slechts soomatisch. Correlaat met deze bepaling van het onderling verschil der twee verticaal contrasterende species is, neopositivistisch, dat der betreffende methodes: bij de natuur past een causaal verklaren, bij de Seele echter een beschrijvende analyse van de structuur der haar inherente activiteit. Op deze wijze is het ons mogelijk, niet slechts op grond van prestasies onszelf te kennen, maar ook, door invoelen, de tijdgenoot en, door navoelen, de medemens uit het verleden te „verstaan", èn in de producten zijner culturele activiteit èn, via het sociale verband, in zijn organisaties, welke twee samen het gebied van "de objectieve geest" uitmaken en als prestaties vanuit de betreffende activiteiten historisch zijn te interpreteren (hermeneutiek). Op het gebied van het willen gelden normen en ideeën; echter niet in theonome zin: Dilthey is in de psychologie, z.i. de basis van alle "Geisteswissenschaften", evolutionist.

ii. De irrationalistische jaren (vanaf plm. 1900). Mettertijd ging Dilthey, meer onder de indruk van Bergson dan van Nietzsches tweede periode, naar de levensfilosofie over. Daardoor ziet ook hij de evolutie thans als een "scheppende". Intussen onderscheidt Dilthey zich van Bergson: het intuïtio- 
nisme was hier verbonden met de belangstelling voor het gebied van de objectieve geest.

Diltheys visie op de geschiedenis is in deze jaren, evenals die van Nietzsche, behalve monistisch ook historistisch. Intusschen is hier noch van overwoekering door evolutionisme noch van nihilisme sprake. Want het gebied van de objectieve geest vergt hier een eigen hermeneutiek, die in de realisatie der menselijke activiteit de rechtvaardiging ziet van ,het leven" in zijn Lebendigkeit. Correlaat daarmee is de Darstellung daarvan, aan welke Dilthey op advies van Husserl thans ook aandacht schonk, een irrationeel bewegende: het historische bewustzijn levert niet alleen mogelijkheden op, maar dient tevens, monistisch iedere theonome zinsbepaling van de geschiedenis afwijzend, genezend in te werken op de nog altijd denken, voelen of willen overschattende en zelf historisch bepaalde wijsgerige systemen. Zo loopt Dilthey's werk uit op een historisme, dat van de irrationele bezinning op het leven verdieping en van de relativering der realisaties bevrijding voor de toekomstige mensheid verwacht.

C. Louter kosmologisch denken.

E. Troeltsch (1865-1923).

Troeltsch, met Dilthey overeenstemmend in de verwerping van iedere theogonische mythe, wijst echter ook elk kosmogonisch denken, inclusief de evolutionistische typen van beide, resoluut af. Positief droeg zijn werk een dualistisch karakter. Daarbij echter de cultuurkritiek, inzonderheid de marxistische, bestrijdend, was hij steeds een noch empiristisch, noch semimystiek, maar monarchiaans Aristotelisme toegedaan in platoniserende zin.

i. De rationalistische jaren (tot plm. 1905).

Onder de invloed van Schleiermacher, gelezen in de neoidealistische geest van W. Windelband's laatste periode, ontwikkelde Troeltsch binnen dit "neokantianisme" der Badense school de leer van een religieus apriori, dat gezocht wordt in het bewustzijn omtrent een objectieve universele wereldziel, die niet met de god der semi-mystiek samenvalt, maar toch, in tegenstelling met het feitelijke Einmalige, in modalistischhumanistische zin "goddelijk" heet en actualiserend op het potentiële Einmalige inwerkt. Hoewel zelf het christendom hoger stellend dan andere religies, wil Troeltsch ook dit oordeel in historische zin zien verstaan: zowel in de theologie 
als in de ethiek dient de dogmatische methode voor de historische plaats te maken.

Toch sloot het historicisme van Troeltsch niet blijvend bij het psychologische type van Windelband aan: zijn conceptie vertoonde mettertijd duidelijk het pneumatologisch type. Vandaar ook, dat hij een neo-pythagorees monade-begrip hanteert, dat, wijl dualistisch, noch aan Malebranche c.s. noch aan Leibniz geöriënteerd is, maar in de moderne wijsbegeerte voor het eerst bij Fr. Merc. van Helmont voorkwam en, door Goethe en Carus in Duitsland bekend, in navolging van Troeltsch, ook een tijdlang in Italië, o.a. bij Groce, een rol speelde.

ii. Irrationalistische jaren (vanaf 1905).

Op de duur kon ook Troeltsch zich niet onttrekken aan de invloed, die het irrationalisme mettertijd mede in de omgeving van Windelband en $\mathrm{H}$. Rickert verkreeg. Vooral de sociologische studies van Max Weber waren van betekenis voor de overgang van Troeltsch naar de levensfilosofie.

Voor zijn geschiedenisopvatting impliceerde dit de aanvaarding van een volslagen historisme: alleen aan dogmatisering en rationalisering schrijft Troeltsch het thans toe, dat individuele en collectieve menselijke verschijnselen, inclusief de cultuur en haar waarden, ondanks hun eigen oorspronkelijkheid niet historistisch worden opgevat.

Intusschen was Troeltsch allerminst blind voor de gevaren die het aanvaarden van deze visie bij Nietzsche c.s. en, schoon in mindere mate, bij Dilthey, begeleiden: met klem bestreed hij in zijn Der Historismus und seine Probleme het nihilisme van Spengler, terwijl hij het evolutionisme herleidde tot een door hem betreurde Engels-Franse invloed op de Westerse cultuur.

Positief eiste hij voor een wijsgerige visie het recht op, speculatief te zijn, mits zij via de formele en reële logika de band met het vakwetenschappelijk onderzoek handhaafde.

Ook nu bleef hij intusschen spreken van monade als tweeeenheid van het Einmalige en het geïndividualiseerde universele pneuma van het rijk der oneindige waarde-mogelijkheden. Maar beide vormen hier een actief geheel, niet van rationeel maar van irrationeel karakter; bovendien berust het rijk der waarde op een vrije scheppende ponering van idealen. Maar het dualisme blijft, zodat ook nu het geheel samengesteld blijkt uit de componenten. Vandaar dat de 
continuïteit der geschiedenis moet worden herleid tot de innerlijke beweging van het goddelijk universele pneuma, door inschouwen te kennen. Voor een universele cultuursynthese levert een dergelijke intuïtie uiteraard geen voldoende basis. Vandaar dat deze synthese hier hoogstens een soort Europeïsme bereikt.

\section{Het Pragmatisme.}

De kritiek in de gangbare wijsbegeerte op het rationalisme beperkt zich er niet toe, het ontbreken te signaleren van een zakelijke basis voor het vertrouwen in de rede met haar apriori's, maar zoekt positief een irrationele compensatie. Van de drie tijdstroomingen in het irrationalisme te onderscheiden, pragmatisme, levensfilosofie en existentialisme, was eerstgenoemde de vroegste.

Haar coryfeeën zochten de oorzaak van bedoeld tekort in het verwaarlozen van de veranderlijkheid zowel bij de wetenschappelijke of practische activiteit, inclusief haar resultaten en de normen van deze, als bij datgene waarop deze activiteit zich bezint of reageert.

Uiteraard hadden niet overal beide zijden gelijke aandacht, en ook inzake de belangstelling voor de theoretische en voor de practische activiteit en het correlaat van beide zijn verschillen op te merken.

Bij de onderlinge divergenties in deze punten valt des te sterker op, dat de oude indeling in hoofdgroepen, typen en neventypen hier overal gehandhaafd blijft. Daarnaast lette men op de chronologie binnen deze beweging.

1. De opkomst van het pragmatisme: C. S. S. Peirce (1839-1914).

Peirce had bijzonder respect voor de "common sense"filosofie der Schotse school en sloot ook voor eigen denken aan bij het niet-evolutionistische dualisme dezer niet-consequente empiristische lijn in het louter kosmologische denken.

Intussen oefende hij hier kritiek niet slechts op Reid's oud-rationalistische leer van de voorstellingen, maar tevens op het neo-rationalisme in deze school: ook de methode draagt immers een redelijk karakter.

Waarop het echter z.i. aankomt is het rechtstreeks ervaren van de dingen in zichzelf, uitkomend in "meanings", symbo- 
lische verbindingen van begrip en woord, welke betrekking hebben op wetten, die, ondanks het ontbreken van volledige gegevens - o.a. inzake de toevallige aanvangsstand van een proces (Peirce's ,tychism") - continuïteit in de processen onderstellen, maar dan ook slechts statistische waarde bezitten. De zin van dergelijke resultaten en van de daaruit logisch afleidbare consequenties is het theoretisch gedrag, daardoor gestimuleerd, niet slechts bij een enkele onderzoeker, maar bij de collectiviteit, bezield door de ,heilige geest der wetenschap", hier als oneindige taak opgevat.

Peirce noemde zijn conceptie "pragmatisme”, maar wijzigde deze aanduiding, toen James haar voor een kosmogonokosmologische en evolutionistische conceptie aanwendde, om verwarring te voorkomen, in "pragmaticisme”.

2. Kosmogono-kosmologisch denken.

Op de voorgrond treden hier vooral monisten.

A. Wisselwerkingstheorie.

i. De evolutionistische typen: James en Dewey.

a. W. James (1842-1919).

James huldigde steeds de zoölogische wisselwerkingstheorie, met haar teleologische inslag. Aanvankelijk laat-rationalist, dus van meetaan voorstander van een teleologisch evolutionisme, was hij eerst aan het universalistische positivisme van Spencer geöriënteerd, later, - onder de indruk van Renouvier's occasionalistische leer van de vrije wil - aan het partiële universalisme met makro-mikrokosmosthema in neopositivistische zin.

Ook James sprak van ,toeval”, dat hier, in een evolutionistisch monisme, echter een reële toevallige verniewing binnen de processen aanduidde. Een dergelijke discontinuïteit liet zich echter, inzonderheid in een monistische conceptie, niet bij continuïteit onderbrengen. Vandaar dat James in 1890 het materiële als discontinu zag, maar - met een beroep op Bergson - het bewustzijn als continu opvatte. Deze opvatting strookte echter niet met de zoölogische wisselwerkingstheorie, volgens welke ziel en lichaam, anders dan bij Bergson, niet verticaal contrasteren. Zo valt te verstaan, dat hij in 1910, naar het voorbeeld van Mach (laatste periode), het bestaan van een ,zuivere ervaring" poneert, die zowel aan de materiële buitenzijde als aan de bewuste binnenkant beurtelings continu 
en discontinu is. Uiteraard raakte zo èn de mathesis èn de mathematische fysika in het gedrang. Een en ander was hier bovendien opgenomen in een partieel universalisme, waarin god als eindige makrokosmos staat naast een veelheid van mikrokosmoi: alleen zó is het volgens James te verstaan, dat het boze bestaat en eveneens dat de mens genoodzaakt is te handelen. Door deze ontwikkelingsgang raakte uiteraard geheel anders dan bij Peirce - de theoretische activiteit in deze conceptie sterk op de achtergrond en bleef in feite slechts de practische over. Daardoor verloor ook het schema binnen-buiten kentheoretisch haar zin: wanneer James een mens in zijn kenbaarheid vergelijkt met een blad papier, dat op een schrijftafel liggend aan de voorzijde wèl, maar aan de achterkant niet valt waar te nemen, tendeert dit reeds naar de vervanging van de oude tegenstelling door die van slechts voor de betrokkene en mede voor anderen kenbaar (G. Ryle).

b. J. Dewey (1859-1952).

Dewey was reeds vroeg de fytologische wisselwerkingstheorie en daarmee binnen het evolutionisme de dysteleologische visie van Darwin toegedaan. Bovendien volgde hij in zijn rationalistische jaren eerst Th. Huxley, een neopositivist van hetzelfde type, en bestudeerde hij daarna Hegel, wiens contradictoire idealisme hij in niet-contradictoire en neorationalistische zin opvatte; zo ontwikkelde zijn belangstelling zich, anders dan bij James, onder wiens invloed hij in 1890 voor het pragmatisme werd gewonnen, bepaald niet in de richting der overschatting van de practische activiteit.

Ook Dewey gaat thans van de experience uit. Op de voorgrond staat daarin, dysteleologisch, het conflict, dat een oplossing vraagt en niet tot probleem mag verrationaliseerd; zelfs de diagnose is geen kennis, maar slechts een middel, waardoor kennis wordt nagestreefd. Kennis is hier dan ook slechts een denkresultaat, dat slaagt. Deze gedachte geldt ook voor de theoretische activiteit: waarheid behoeft niet iedereen te voldoen - dit is, gezien de invloed van fantasie en bijgeloof onmogelijk - maar de mannen van wetenschap, en bij deze activiteit behourt 0. .a. mede het ontdekken, dat een hypothese te kort schiet. Voorts schuilt de onzekerheid niet bij ons, maar bij de veranderende natuur, die ons uitdaagt, haar zowel theoretisch - met behulp vooral van hypothesen - uit te vragen als practisch te veranderen. De mens mag dus niet machteloos dromen: hij kan, al worstelend verder komend, 
een beperkte zekerheid bereiken, die te omschrijven en te verifiëren valt.

ii. Het niet evolutionistische type.

G. Milhaud (1858-1918) vertegenwoordigt in de Franse wetenschapskritiek de anthropologische wisselwerkingstheorie.

De lijn van Descartes in het pragmatisme doortrekkend, opponeert Milhaud vooral tegen het al of niet empiristisch positivisme, dat de menselijke denkgeest als een registratie-apparaat beschouwt: geen wetenschap is immers mogelijk zonder de scheppende activiteit van deze geest.

Bij het kennen van de verschijnselen speelt nl. naast waarneming en experiment de taal der mathesis met haar ficties een belangrijke rol. Tussen deze twee kanten van het wetenschappelijk werk nu bestaat geen logisch verband: wie zich aan de voorschriften van Fr. Bacon en Comte houdt, geen enkele verkeerde stap te doen, verzet op den duur geen voet.

De wetenschap kan echter niet buiten ficties als ,het oneindige", ,aantrekkingskracht" enz. En deze ficties zijn niet bewust-onware hulponderstellingen, die tijdelijk worden ingelast om later weer te worden geëlimineerd (Vaihinger), maar het product der vrije en contingente scheppende activiteit in de denkgeest. Met deze vrijheid verdraagt zich geen determinisme, daarentegen wel de taak zo mogelijk de verschijnselen niet slechts te verstaan, maar te zien aankomen en ze steeds beter te benutten. Comte's leer der drie stadia moet dan ook met een vierde - dat der denkende innerlijkheid - worden aangevuld.

B. Prioriteitsleer.

i. De niet evolutionistische vleugel.

(J.) H. Poincaré (1894-1912) werkte, iets vroeger dan Milhaud, in gelijke geest, zich daarbij intusschen baserend op de ennoëtistische lijn Newton-Haupertuis-Kant, in Frankrijk tijdens het neorationalisme voortgezet in niet-evolutionistische geest o.a. door d'Alembert en Lachelier.

ii. De evolutionistische vleugel.

Daarentegen huldigde Ed. Le Roy (1870-1954), al vóór Bergson, een irrationalistisch instrumentistisch evolutionisme, dat hij aanvankelijk in pragmatistische zin uitwerkte. Ook deze conceptie wekte natuurlijk Poincaré's verzet.

C. Parallelisme.

F. C. S. Schiller (1864-1937), een Engelse pragmatist, 
keerde zich scherp tegen Hegel en koos, beïnvloed door W. Wundt en diens pleitbezorger in Engeland, J. Ward, voor het begrensde parallelisme partij en daarmee voor een evolutionisme in de geest van Galton's biometrie. Ook z.i. is de werkelijkheid niet vast, maar een plastisch gegeven, waarop denken en handelen veranderend ingrijpen. Beide activiteiten ressorteren hier onder een doelstellend bewustzijn.

Voor het practische handelen is het geloof aan vrijheid bevorderlijk, daarentegen is het denkend handelen voor zijn voorspellingen op deterministische onderstellingen aangewezen. Waardevol is een antwoord, wanneer het aan de zin der vraag en aan de bedoeling van de vrager beantwoordt: slechts dan werpt het theoretisch nut af, dat men niet met practisch nut en vooral niet met oeconomisch voordeel vereenzelvige.

3/4 Louter kosmologisch en mythologiserend denken.

Ook deze hoofdgroepen van typen zijn in het pragmatisme vertegenwoordigd: men denke hier o.a. aan de semimystiek van Dempf en aan het monarchiaanse intellectualisme van Driesch, Groos, Vailati, Münsterberg en E. Lask in de eerste groep en wat het mythologiserende denken betreft, aan de complexenpsychologie van C. G. Jung.

\section{De levensfilosofie.}

Ook deze strooming draagt een irrationalistisch karakter.

De terminologie is speciaal hier niet bepaald helder: men denke bij "levensfilosofie" noch aan „wijsbegeerte voor het leven", noch aan een theoretische overschatting van het biotische (biologisme of vitalisme): de levensfilosofie stelt het leven als het innerlijke en continue tegenover het uiterlijke en discontinue. Met andere woorden: men interesseert zich hier primair niet voor de houding van de mens ten opzichte van het veranderlijke, is dus een stap verder in de richting van het subjectivisme dan de pragmatist, die in die milieu dan ook nogal eens als „burgerlijk” wordt afgedaan of voorbijgestreefd.

Ook binnen de levensfilosofie is het spraakgebruik onduidelijk: „innerlijk” betekent ook wel het hogere, soms zelfs het lagere.

Ook hier gaat de indeling in hoofdgroepen, grond- en neventypen door.

1. Mythologiserend denken: Sorel en Spengler.

A. George Sorel (1847-1922). 
Sorel, een Frans ingenieur, huldigde, evenals Marx, met wie hij ook de cultuurcritiek gemeen heeft, een dualisme zonder dichotomie: geheel het mensenleven met zijn tegenstelling van morele decadentie en steeds verder voortschrijdende techniek ressorteert onder het niet-transcendente. Redding is slechts van de politiek te wachten. Maar van welke?

De verscheidenheid in de beantwoording van deze vraag bepaalde in niet geringe mate de wijsgerige ontwikkeling van Sorel.

In 1898 nog rationalistisch socialist, gaat hij kort na 1900 onder invloed van Bergson naar de levensfilosofie over: niet de rede, maar instinct en intuïtie zijn nodig. Intusschen deelde Sorel met Bergson niet het monisme: hij bleef dualist; vandaar dat hij in de kenleer de beeldentheorie volgt. En dan uiteraard in mythologiserende zin: uit de beelden ontstaan mythen.

Het revolutionaire sentiment wortelt ook hier in de ontologie: Sorel staat, evenals Feuerbach en Marx, wantrouwend tegenover het trancendente; en de menselijke natuur is zwak: zij valt vanzelf aan de decadentie met haar ongelijkheid ten prooi. Vernieuwing is slechts te wachten van oorlog, geweld en klassenstrijd in de zin van het revolutionaire syndicalisme.

Dit program liet echter verschil in uitvoering toe. In 1912 is deze tendentie verbonden met het nationalistische streven in Frankrijk, sinds 1918 met het internationale doeleinden nastrevend bolsjewisme. Het doel bleef echter hetzelfde: negatief de bestaande uiterlijke beschaving te gronde richten, terwijl positief de arbeidersbeweging door eigen inspanning op het morele peil dient te komen, waarop zij de techniek der moderne industrie innerlijk aan kan.

B. Oswald Spengler (1880-1936).

Ook Spengler dacht mythologiserend. Intusschen verschilde hij sterk van Sorel: Spengler was historicus en wijsgerig aan Nietzsche's Der Wille zur Macht geöriënteerd. Hij is dan ook monist in de geest van het Chaldeesche parallelisme: de oorsprong van alles is de Tijd, die verticaal divergeert in Hemel en Chaos en deze in Aarde en Onderwereld. Het aardse leven weerspiegelt dat aan de hemel.

Ook hier is de mens één, in monistische zin. Maar in de tegenstelling van geschiedenis en natuur, van het wordende en wat werd, van tijd en ruimte. Deze tegenstelling dekt echter, 
volgens Spengler, tevens die van organisch en mechanisch! Historische culturen zijn z.i. dan ook te vergelijken met vegetaties, innerlijk beheerst door Schicksal, dat, synchronisch verlopend met het gebeuren in den sterrenhemel, haar van binnen uit bepaalt, uiterlijk door causaliteit.

„Diepte" staat daarbij tegenover „oppervlak", „tijd en „leven" tegenover „ruimte en dood", ziel tegenover intellect, schouwende wijsheid tegenover wetenschap.

De grondtoon is dus nihilistisch, maar niet over de gehele lijn pessimistisch. Toegepast op de situatie van Europa in 1918 is echter de diagnose: de Westerse cultuur is, als geheel veruiterlijkte civilisatie, ten ondergang gedoemd.

2. Kosmogono-kosmologisch denken: Simmel en Bergson.

A. Georg Simmel (1858-1918).

Aanvankelijk aanhanger van een evolutionistische wisselwerkingstheorie, wordt hij voorzichtiger door de bestudering van Kant (1903). Intusschen aanvaardde hij ook toen nog apriori's. Mettertijd gaat hij echter over naar de levensfilosofie. Zijn monisme wordt nu een contradictoir.

Leven in engere zin staat ook hier, als continu innerlijk gescheiden, met een elkander doordringen van nog niet - nu - niet meer in het aspect van de tijd tegenover het uiterlijke met zijn tijdloze vorm.

Maar daarbij blijft het in dit geval niet: het leven kan de uiterlijke vorm niet missen; doch het is daaraan niet gebonden: het schrijdt over de grenzen van zijn vorm heen.

Daarbij geldt ook het principe der uit te sluiten contradictie niet: het leven blijft worden zonder enige grens. De vorm wordt hier dus in vitale en esthetische zin aanvaard, maar niet ${ }^{\circ}$ als autonoom gebied: waar dit gevaar dreigt revolveert het leven. Zo omspant dit leven tragisch, zelfs de dood als fenomeen.

B. Henri Bergson (1859-1941).

Ook Bergson was kosmogono-kosmologisch monist. Anders dan Simmel sluit Bergson echter bij de prioriteitsleer met impetustheorie aan: daardoor verstaat hij onder het innerlijke de ziel, onder het uiterlijke het lichaam, en valt het innerlijke hier dus met het hogere samen.

Dit hogere is onophoudelijk veranderend en scheppend, waarbij het volgende moment het vorige insluit. Bovendien 
komt daarbij de menselijke intuïtie uit het dierlijke instinct op (evolution creatrice). Daarentegen is het lichaam ruimtelijk, zodat geen twee lichamen op dezelfde plaats zijn. Intusschen valt hier het organische van het anorganische te onderscheiden; het laatste is uitsluitend werktuig, maar een lichaan van dier en mens kan, door de ziel in beweging gebracht, haar helpen aan de uitdrukking in een gebaar.

Een en ander is niet slechts individueel, maak ook, en zelfs primair, universeel. En bovendien mystiek gedacht.

\section{Louter kosmologisch denken: Ludwig Klages (1872-} 1956).

Klages behoort ontologisch bij de niet-consequente empiristen, nader tot het platoniserend type, dus tot de lijn die van de Schotse school over Palagyi naar Peirce liep. Daaraan is toe te schrijven, dat het leven van de tijd hier, evenals bij Sorel, bij het bezielde niet-transcendente behoort, daarentegen de geest transcendent is.

Eerstbedoeld terrein is hier dat der rechtstreeksche ervaring van het leven: lijn, kleur en geur zijn levende machten, niet als eigenschappen der dingen te onderscheiden, maar als "wezen" te identificeren. Ook Klages spreekt, evenals Sorel, dualistisch van "beelden", maar uiteraard niet van mythen. Kentheoretisch is dit het gebied van het schouwen.

Het ik omspant zowel dit niet-transcendente leven als de geest. De onderlinge verhouding van laatstbedoelde twee is echter een beslist vijandige: de (denk)geest pleegt in het menselijk bestaan inbreuk en beoogt met zijn opvatten en willen het leven zelfs te "doden".

Dat het lagere ondanks zijn continuïteit als ding wordt gezien is daaraan te wijten, dat de geest zich in het leven spiegelt en zo daarin slechts zichzelf waarneemt (Narcissusthema).

De strekking van Klages' visie is dan ook, het denken zonder meer op te heffen.

\section{Het existentialisme.}

De derde en vooralsnog laatste strooming binnen het irrationalisme in de Westeuropese wijsbegeerte is het existentialis$m e$, dat vooral in Frankrijk, Duitsland en Italië aanhang vindt.

Existeren is het individuele bestaan, dat nooit zonder iets universeels is: „deze" spreeux is een "spreeuw". Dit existeren 
is in het existentialisme echter beperkt tot het irrationele bestaan van een mens, wellicht het beste te omschrijven in de zin van ,het vrijmachtig zich verhouden tot zichzelf, gezien als het historisch gebeuren van het op weg zijn naar zichzelf" (Zuidema).

Intusschen leide men daar niet uit af, dat een existentialist noodzakelijk een individualist zou zijn: meer dan eens blijkt dit bepaald niet het geval. - De uiteenzetting draagt in dit milieu vaak de vorm van artistieke literatuur, wat uiteraard meer de suggestieve propaganda dan de verheldering der conceptie ten goede komt.

Ook deze visie is echter slechts concreet in de grote verscheidenheid van types, reeds in het rationalisme op te merken.

1. Louter kosmologisch denken.

Nimmer evolutionistisch, kent het zowel niet individualistische als individualistische typen.

A. Niet individualistische typen.

Het partiële universalisme (zonder makro-mikrokosmosthema) der belangrijkste typen (Jaspers en Lavelle) is een niet empiristisch, maar intellectualistisch platoniserend aristotelisme. Men onderscheide hier het monarchiaanse en het semimystieke type (2).

i. Karl Jaspers (1833_...), Duits psychiater en filosoof, 1921 hoogleraar te Heidelberg; gehuwd met een Joodse, verloor hij in 1937 zijn professoraat. Jaspers boog op de platoniserende vleugel van het monarchianisme het noölogisch type der Heidelbergse school $-\mathrm{H}$. Rickert (neo-idealist), E. Lask (pragmatist) en M. Weber (levensfilosoof) - in existentialistische zin om.

Dit dualisme stelt ook hier het transcendente tegenover al het overige, het niet-transcendente. In dit laatste zijn correlaat met elkander het éne, universele en actuele wereld intellect (,Vernunft", hier natuurlijk niet op te vatten als "rede": Jaspers brengt de term in verband met „vernehmen") en het overige, dat individueel en potentieel is en mede bij een mens bestaat uit een combinatie van ziel (vorm) en lichaam (materie). In genoemde correlatie is het wereldintellect als cultuurgeest het hogere en blijvende, het overige het lagere, dat bij de dood geheel wegvalt.

De twee polen in deze conceptie zijn dan ook existeren 
en transcenderen. Terwijl de psychologie ook van de mens zich beperkt tot een „verklaren”, raakt het „verstaan" - hier (anders dan bij Dilthey) in de cultuurfilosofie geplaatst zijn verhouding tot het bovenpersoonlijk wereldintellect met zijn waardevolle intermenselijke "communicatie”, waarbij het komt tot beslissingen van een bepaald type (eidos) en van een bepaalde kracht (idee). Jaspers stelt zich nu tot taak, de zich hier voordoende mogelijkheden te verhelderen en te appelleren op de vrije beslissing van het individu in zijn contact met de Vernunft. Deze verheldering leidt primair tot de onderscheiding van oneigenlijk en eigenlijk existeren, d.u.z. existeren los van de Vernunft - o.a. in de welvaartsstaat en in contact met deze. In het eigenlijk existeren geraakt een mens in situaties die ons aan de grens van ons Dasein brengen en geheel de existentie doen wankelen, daar zij nergens vastheid kan vinden. Uit de mogelijkheden, bij zulk een grenssituatie zich voordoend, moet men kiezen; maar iedere keuze blijft een wagen daar het transcendente zwijgt en moet zwijgen, wil de vrijheid der existentie niet worden opgeheven. Men kieze dus in trouw aan zichzelf, maar wete, dat op den duur een "schipbreuklijden” onafwendbaar is: met hen die aan een opstanding geloven is geen „Kommunikation” mogelijk.

ii. Louis Lavelle (1883-1951), Frans wijsgeer en uitne mend stilist, aanvankelijk neo-idealist in de geest der semimystiek van W. Windelband (voorlaatste fase), ging onder invloed van Bergson, naar het irrationalisme over; daarbij bleef hij aan bedoelde semi-mystiek trouw, waarin echter de levensfilosofie (Blondel) hem niet bevredigde.

Anders dan bij Jaspers valt de tegenstelling van transcendent en niet-transcendent hier samen met die van immaterieel en materieel. Daardoor ligt de correlatie actueel-potentieel hier binnen het immateriële: de God dezer conceptie is louter actus; de mens daarentegen, voorzover immaterieel, potentieel. Het geheel is ook hier irrationalistisch gedacht. God is nu, naar humanistisch ideaal, zichzelf scheppend proces, dat waardekarakter draagt. In de menselijke existentie staat het geweten als subject in verband zowel met het innerlijke (hier hogere) Absolute, dat ons met zijn waarden steunt, als met het uiterlijke (hier lagere), dat ons als materie kansen biedt. Bij de keuze ten goede komt het tot incarnering van waarde, bij de keuze ten kwade staat ons willen echter afwijzend tegenover het zijn en de waarden. 
B. Individualistische typen.

Jean Paul Sartre (1905-...), Frans wijsgeer en literator, was reeds vroeg aan het niet-artistotelische louter kosmologische denken georiënteerd; existeren is hier daarom van meetaf individualistisch. In de ontwikkelingsgang van zijn atheïsme onderscheide men een monistische en een dualistische fase.

i. Monisme.

Sartre dacht lange tijd materialistisch en politiek anarchistisch: existeren is individuele vrijheid, die orde en wet, waarde en essentie scheppen kan, maar in dit alles onafhankelijk en onbepaald blijft, en, op zichzelf teruggeworpen, als historisch gebeuren tot zijn dood ondefinieerbaar is. Daar Sartre het psychische als materieel ziet, is zijn voornaamste tegenstelling die van het en-soi der ons omringende natuur en het pour-soi der menselijke existentie, die altijd wordt en daarom is wat zij niet is en tegenover de natuur als néant, vernietsend staat. Ook de verhouding tot de medemens is negatief: de naaste is de hel en het samenleven één conflict.

ii. Dualisme.

Later in contact gekomen met Simone de Beauvoir gaat Sartre binnen het louter kosmologische denken tot een dualisme zonder dichotomie over. Hij onderscheidt nu uiterlijk lichaam en innerlijke handeling. Ook de samenleving is niet meer noodzakelijk conflict met andere individuen: de klassestrijd impliceert de tegenstelling van een collectief onderdrukkend "sujet" en een eveneens collectief object, dat door aanvaarding van de gemeenschappelijke situatie een "nous" wordt. Een alle menselijke existenties aanvaardend "nousobject" is niet mogelijk, daar dit als correlate pool een nietmenselijk, maar goddelijk "sujet" zou vragen, dat niet bestaat. Door de overgang naar genoemd dualisme werd het type van Sartre's denken hetzelfde als dat der communisten. Toch verschilt zijn conceptie, als existentialistisch, duidelijk van die bij Marx c.s. Dat Sartre zich dit ook zelf bewust is blijkt o.a. uit zijn krachtig verzet in zijn Critique de la raison dialec. tique I (1960) tegen het bij Marx c.s. heersend rationalisme en in het z.i. daarachter schuilend Hegelianisme.

2. Kosmogono-kosmologisch denken.

De belangrijkste figuren zijn hier monisten. 
A. Wisselwerkingstheorie.

Maurice Merleau Ponty (1908-1961), 1952 hoogleraar aan het Collège de France, reeds vroeg existentialist, was aanvankelijk een leerling van Sartre, maar distantieerde zich geleidelijk al verder van hem. Positief huldigde hij het evolutionisme der zoölogische wisselwerkingstheorie. De mens is een eenheid van lichaam en bewustzijn d.w.z. van materiële objectieve buitenkant en een subjectief innerlijk; als eenheid (corpssujet) wordt dit tweezijdige bestaan doorleefd in de ervaring der waarneming. Deze conceptie verbond M.P. met Husserl's fenomenologie, hier uiteraard omgewerkt in existentialistische zin. De menselijke zelfbepaling is, ook in zijn zelfontwerpen van persoon en toekomst, mede door de contingente situatie bepaald, dus zelf-situering. Onder het contingente ressorteren ook de medemensen. Existeren is hier dus het proses niet van één mens in conflict met al de anderen, maar van velen, en dan niet in klassestrijd maar in onderlinge ontmoeting, die ook onze zelfkennis bepaalt. Intusschen blijft existeren het onderueg-zijn van mensen naar zichzelf: ook dit monisme is nóch pantheïstisch, nóch partieel theïstisch, maar atheistisch.

\section{B. Prioriteitsleer.}

Gabriel Marcel (1889- ...), Frans dramaturg-filosoof, was tot 1914 neo-hegeliaan, maar koos later voor een verbinding van existentialisme met prioriteitsleer in niet-evolutionistische zin. Daardoor naderde hij Le Senne, met wie hij ook het partiële universalisme gemeen had, maar van wie hij zich onderscheidde door aan te sluiten niet bij het occasionalisme, maar bij het ennoëtisme, in Frankrijk reeds voordien door Poincaré in pragmatistische zin omgebogen.

Marcel was het intusschen niet slechts om wetenschapscritiek te doen: hij stootte door tot de metaphysische wortels van het ennoëtisme, die sinds Kant c.s. door de kentheorie op den achtergrond waren geraakt. In deze „ontologie mystérieuse" divergeert bij de mikrokosmoi de oorsprong - het zijn (l'être) - verticaal dan ook niet zoals bij Le Senne, in menschelijke „ziel” en dierlijk „lijf”, maar in een geest (esprit) en een lichaam, die beide menselijk zijn. De oorsprong zelf valt uiteraard met geen van deze twee samen: het ik is noch esprit, noch lichamelijk Ding an sich, doch het ééne, niet uit, maar achter en in die twee. En dan niet in dezen zin, dat 
het beide zou bezitten. Want ieder "avoir" zelfs het wederkeerig menschelijk, impliceert bij de partners een existeeren als mensch, in subject en object, in "esprit" en "corps" „geincarneerd". - Men vereenzelvige hier vooral niet "vleesch" (caro) met „lichaam": Marcel's „,homme incarné” heeft niets met het uitermate dualistische transmigratie-thema te maken! - Daarom is ook "de andere" hier niet een gegeven voor mijn bewustzijn, maar medemens, een „gij”, als correlaat van een ,ik". Van deze mikro-kosmisch existeerenden onderscheidt de eveneens geïncarneerde makrokosmos zich als universeel en goddelijk van individueel en menselijk en als het centrum bij een cirkel van punten op de periferie. Zo liggen religieus en intermenschelijk verband, hoewel als straal en koorde allerminst ident, hier in hetzelfde religieuse vlak.

Sedert zijn overgang naar het christendom (1929) in synthetische geest ziet Marcel de wanhoop der ondergangsstemming scherp tegenover de hoop, mede op een leven na de dood.

Intusschen blijft de monistische trek ook in motiveering van zijn idealen voor de praktijk: de zelfvervreemding wijt Marcel niet aan het kapitalisme, maar aan het dualistische nivelleringsideaal: met vrijheid verdraagt zich wel de broederschap (morele herbewapening), maar niet de gelijkheid, die immers tot concurrentie leidt.

Hoewel Marcel, in Frankrijk door Sartre overvleugeld, zijn conceptie in latere jaren liever "neo-socratisme" dan existentialisme noemt, bleef de grondgedachte dezelfde: tegenover het "hebben" met zijn spanning tusschen subject en object, bij welke z.i. ook de wetenschap leeft, staat de wijsbegeerte van het zijn voor de onoplosbare mysteriën der ik-gij relaties in religie en medemenselijkheid.

3. Mythologiserend denken.

M. Heidegger (1889-...) ontwikkelde zich mettertijd eerst van louter kosmologisch tot kosmogono-kosmologisch denker en kwam nog later bij het mythologiserend denken uit.

A. Zijn niet-existentialistische jaren (vóór 1926) dragen een uitsluitend kosmologisch karakter in de zin van een platoniserend dualisme. Uit r.k.-milieu afkomstig, huldigde $\mathbf{H}$. aanvankelijk de subsistentie-theorie, eerst in neo-positivistische zin van Brentano ( $2 \mathrm{e}$ fase), later in neo-idealistische (invloed van Geyser). Mettertijd voegde hij zich bij het 
monarchianisme, eerste van Rickert (neo-idealist) later van E. Lask (pragmatistisch irrationalist).

B. Tijdens zijn kosmogono-kosmologische jaren (1926plm. 1932) was Heidegger aan de zoölogische wisselwerkingstheorie van Husserl georiënteerd. Intusschen werkte hij diens fenomenologie in existentialistische zin uit: het fenomenologisch denken betreft niet slechts het object maar ook het gehele Dasein waarin speciaal dat van de mens aandacht verdient.

Dit menselijk Dasein nu is, zolang het zich „besorgend" met objecten en "fürsorgend" met medemensen (het gebied van het „Man") bezighoudt, oneigenlijk; van eigenlijk Dasein is eerst sprake waar de mens zich èn geworpen (Befindlichkeit) èn ontwerpend (in zijn Entwurf) tot zichzelf verhoudt. De zijnszin van het zijnde ligt in de tijdelijkheid; daardoor is de tijd de horizon voor het verstaan van het zijn en voor de interpretatie daarvan in de taal - scherp te onderscheiden in het "Gerede" in de wereld van het "Man".

Dit eigenlijke "Dasein" staat tegenover het bestaan der dingen als het negatieve, dat zichzelf "niet” en daarmee het zijnde overschrijdt. Dit transcenderen versta men hier in monistische zin: het is horizontaal. In de angst ontglijdt het zijnde in een niets, waaruit het zich echter tegelijk aan het Dasein toekeert. Eerst op deze, door de verbinding met de fenomenologie vereiste wijze, is het zich verhouden tot zichzelf als gebeuren en het zich in distantie verhouden tot de dingen mogelijk.

C. Mythologiserende jaren (1933_...). Viel reeds tijdens de vorige periode in zijn terminologie de invloed van Spengler te bespeuren, mettertijd belandde Heidegger volledig bij diens nihilisme, uiteraard in existentialistische geest omgezet. Hiermee strookt politiek zijn houding ten opzichte van Hitler c.s. en wijsgerig zijn waardering, in tal van publicaties, voor Hölderlin, die in het oude idealisme hetzelfde type vertegen woordigde.

Met deze overgang naar het mythologiserend parallelisme houdt ook de wijziging in zijn terminologie verband. Het zijn van de in z'n zelfdifferentiëring idente oorsprong staat als het ene subject tegenover al het daaruit ontsprongene in hemel en in aarde en in onderwereld, dat object is. Deze oorsprong 
is echter de Tijd als gevende en waarborgende Natuur. Binnen de wereld der objecten verloopt het gebeuren op aarde parallel met dat in de hemel: in beide onderscheidt $\mathrm{H}$. met de Chaldeïsche astrologie vier windstreken. Daar echter dit gebeuren niet zonder objecten plaatsvindt is het niet meer dan een spel en de mens heeft hier dan ook de taak zich in dit spel te voegen.

\section{Amsterdam.}

D. H. Th. Vollenhoven.

1) Inclusief de culturen in Amerika en Zuid-Afrika, voorzover tot de Westeuropeesche te herleiden.

2) „Subjectivisme” staat daarbij tegenover „objectivisme" en bovendien, samen met het objectivisme, tegenover het ",realisme". Deze termen kunnen bij de beschrijving van het Grieksche denken, dat voornamelijk ontologisch is, primair niet in kentheoretische zin worden gebruikt, daar zij hier alle betrekking hebben op de quaestie van de plaats der wet: het subjectivisme zoekt de wet in de (niet uitsluitend menschelijke!) subjecten, het objectivisme in de objecten en het realisme buiten die twee in een "mundus intelligibilis". Voor nadere explicatic van de hier en in volgende noten verduidelijkte termen mag ik wel verwijzen naar mijn Geschiedenis der Wijsbegeerte, I, Franeker, T. Wever, 1950. Voorts Phil. Ref. XXVI (1961), pp. 135 e.v. „De consequent probleemhistorische methode".

3) Onder "mythologiseerend denken", dat bij de Grieken op Mousaios en Hesiodos teruggaat, versta men uitsluitend een denken, dat in zijn wijsbegeerte aan de mythe van pagane religies is geöriënteerd (dus niet mythen terloops aanhaalt of zelfs uit didactisch oogpunt vormt, wat o.a. bij Plato geschiedt); dit denken heeft primair betrekking op de wording van goden en kosmos en kan dus ook theogono-kosmogonologisch worden genoemd. Zijn antipode is het louter kosmologische denken van filosofen als Thalès en Xenophanès, dat primair slechts antwoord geeft op de vraag: „wat is?" en daarom ieder worden, dus èn dat van den kosmos èn dat der goden als voor de wijsgeer bijkomstig beschouwt. Het midden tusschen mythologiseerend en louter kosmologisch denken houdt het kosmogonokosmologische, dat niet van de wording van goden spreekt, maar wel die van den kosmos tracht te verklaren.

4) Dualisme en monisme hebben beide betrekking primair op de verticale structuur der dingen. Het dualisme gaat daarbij uit van de correlatie tusschen het transcendente en het niet-transcendente ook deze termen uitsluitend in ontologischen zin genomen - die ook wat de tijdsduur betreft gelijkwaardig zijn: derhalve zijn volgens den dualist het transcendente en het niet-transcendente of beide eeuwig of beide even oud. Het monisme daarentegen vangt aan bij éen aan al het daaruit ontspringende inhaerente oorsprong, uit welke al het overige door verticale divergentic ontstaat. 
Grafisch:

\section{Transcendent}

Dualisme niet-transcendent

Monisme Oorsprong

Het Christendom is dus nòch dualistisch, nòch monistisch.

5) Deze tegenstelling raakt uitsluitend de anthropologie: een dualisme zonder dichotomie rekent geheel den mensch tot het niet-transcendente; daartegenover poneert het dualisme met dichotomie, dat ook hetzij bepaalde menschen - nl. uitsluitend mannen - hetzij alle menschen - dus zowel mannen als vrouwen - iets transcendents bezitten.

6) De onderscheiding van wisselwerkingstheorie, parallelisme en prioriteitsleer raakt in de eerste plaats verschillen in de leer omtrent de onderlinge verhouding van de met elkander contrasteerende uitloopers der primaire divergentie. Bij de wisselwerkingstheorie werken deze twee op elkander in, bij het parallelisme is de verhouding er een van horizontaal loopende evenwijdige lijnen, die slechts het punt van de oorsprong gemeen hebben en dus beide bovendien parallel loopen met de lijn van „,de derde onbekende”, horizontaal door het divergentiepunt getrokken, wier „phaenomenen" de twee andere zijn. De term "prioriteitsleer" is niet gangbaar - het betreffende type word nauwelijks in zijn eigenaardigheid opgemerkt - en vergt daarom eenige toelichting: de prioriteit die de hoogere uitloopers ten opzichte van de lagere heeft bestaat daarin, dat de eerste zich wel op een of andere wijze met de tweede bezig houdt, maar harerzijds geen invloed van het lagere ondervindt.

Grafisch voorgesteld:

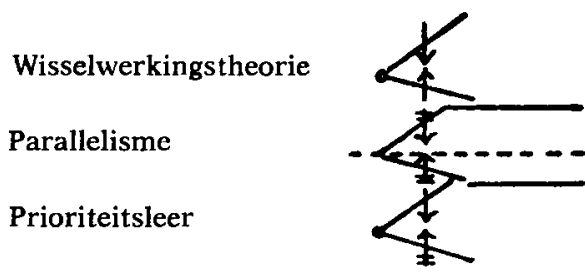

Men vereenzelvige de hier bedoelde verhoudingen tusschen de verticaal contrasteerende uitloopers der primaire divergentie niet met de verscheidenheid van ziel en lichaam: laatstbedoelde is bij de wisselwerkingstheorie zelfs een horizontale.

7) Intellectualisme onderscheide men scherp van rationalisme: het eerste is niet een tijdstrooming, maar een type: het kwam reeds bij Aristoteles voor en kruiste bij Vico c.s. het rationalisme.

8) "Idealisme" in wijsgeerigen zin vereenzelvige men, om verwarring te voorkomen, vooral niet met "rationalisme": het is daarin, zowel bij het vroege als bij het late rationalisme, slechts de laatste tijdstrooming, die de twee voorgaande verbindt.

9) Voor Dilthey moge ik hier naar III verwijzen. 


\section{LITERATUUR:}

W. Dilthey: Weltanschauung und Analyse des Menschen seit Renaissance und Reformation (Ges. Schrifte, Bnd 2, 1914).

R. Hall: The scientific revolution 1500-1800 (1954, 2e dr., 1962). Bulletin de l'étude du $17 \mathrm{me}$ siècle (1949 v.v.).

R. Kroner: Von Kant bis Hegel, I-III (1921-1924).

E. Troeltsch: Die Dynamik der Geschichte nach der Geschichtsphilosophie der Positivismus (1919).

R. Bayer: Epistèmologie et logique depuis Kant jusqu' à nos jours (1954).

F. Coplestone: A History of Philosophy VII (1963).

H. Weichelt: Nietzsche, der Philosoph des Historismus (1924).

Gw. O. Griffith: Interpreters of man (1943).

O. F. Bollnow: Dilthey (1936", 1955).

K. Kuypers: Mens en Geschiedenis bij Dilthey, Alg. Ned. Tijdschrift voor Wijsb. en Psychol. 54 (1962), pg. 61-75.

W. Bodenstein: Neige des Historismus, E. Troeltsch's Entwicklungsgang (1959).

J. Dewey a.o.: Creative Intelligence (1917).

E. Waibel: Der Pragmatismus in der Geschichte der Philosophie (1925)

Ph. P. Wiener: Evolutionism and the Founders of Pragmatism (1949).

G. Misch: Lebensphilosophie und Phaenomenologie (19132, 1931).

Ph. Lersch: Lebensphilosophie der Gegenwart (1932).

J. Benda: De quelques constantes de l'esprit humain (1950).

O. F. Bollnow: Die Lebensphilosophie (1958).

J. Wahl: Petite histoire de l'existentialisme (1946).

S. U. Zuidema: De mens als historie (1948).

W. Kamlah: Der Mensch in der Profanität (1949).

H. Redeker: Existentialisme (1949, 1956").

F. Heinemann: Jenseits der Existentialismus (1957).

J. van der Hoeven: Kritische ondervraging van de fenomenologische rede (1963). 